Discourse and Communication for Sustainable Education, vol. 10, no. 2, pp. 60-71, 2019

\title{
Makerspaces as Social Innovation and Entrepreneurship Learning Environments: The DOIT Learning Program
}

\author{
Guntram Geser, Eva-Maria Hollauf, \\ Veronika Hornung-Prähauser, and Sandra Schön \\ Salzburg Research, Salzburg, Austria \\ Frank Vloet \\ Waag, Technology \& Society, Amsterdam, Netherlands
}

\begin{abstract}
Developing social innovation and entrepreneurship competences and skills of children and young people is on the agenda of European educational policy-makers. The European research and innovation project "DOIT - Entrepreneurial skills for young social innovators in an open digital world" suggests using makerspaces and tools, within schools and externally, to promote practice-based social innovation and entrepreneurial learning of children and young people. This article first gives an overview of different types of makerspaces, addresses the concept of maker education, and highlights common development goals of such education with entrepreneurship education regarding particular attitudes and competences. The main part then describes the DOIT learning program that allows children and young people (6-16 years) to acquire skills and an entrepreneurial mindset for turning creative ideas into potential social innovations. This program is currently trialed in DOIT pilots in different types of makerspaces in ten European countries. The article describes learning processes and outcomes that are promoted by the program with two examples that are different regarding the makerspaces, topics and other aspects. Some first experiences and lessons learned from these and other pilots are summarized.

Key words: entrepreneurial education, maker education, makerspaces, social innovation, sustainability.
\end{abstract}

\section{Introduction}

The European research and innovation project "DOIT - Entrepreneurial skills for young social innovators in an open digital world" is a 3-year Horizon 2020 Innovation Action (October 2017 -September 2020) that designs, trials and evaluates a new approach allowing young people to develop an entrepreneurial mindset and skills for turning creative ideas into social innovations. DOIT suggests applying practice-based learning in makerspaces to foster digital, social and entrepreneurial competences of young people 
(6-16 years old). Specifically, the project proposes co-creative maker activities addressing societal issues.

Issues of sustainability and sustainable solutions are considered in DOIT pilot actions on themes such as Environment and Nature (e.g. sustainable use of resources, waste management), Living Together (e.g. environmental and social issues in local community), Wellbeing, Health and Sport (e.g. healthy food and activities). The DOIT pilot actions invite children and young people to use maker methods and tools to develop creative, awareness-raising, and potentially sustainable solutions.

This article first gives an overview of different types of makerspaces (FabLabs, hackerspaces and others). As far as makerspaces already have made it into educational institutions and other learning contexts (e.g. libraries, museums), the predominant approach today is learning of Science, Technology, Engineering and Mathematics (STEM). This approach tends to narrowly focus on promoting basic technical knowledge and skills through using digital fabrication tools (e.g. 3D design and printing) or programmable tools (e.g. Arduino, Makey Makey, Raspberry Pi) for sensors-based, robotics and other applications. The DOIT learning program represents a different paradigm of maker education that focuses on practice-oriented social innovation and entrepreneurial learning of young people (aged 6-16 years) based on activities in makerspaces. This distinguishes the DOIT program from makerspace-based STEM learning, but also from typical Entrepreneurship Education. However, the program shares common development goals with entrepreneurship education regarding particular attitudes and competences.

The following sections then describe the DOIT learning program that is currently trialed in DOIT pilots in different types of makerspaces in ten European countries. Learning processes and outcomes that are promoted by the program are described with two examples that are different regarding the makerspaces used, the topics of the social innovation projects designed and other aspects. Some first experiences and lessons learned from these pilots are summarized. The DOIT pilot teams experienced makerspaces, in their different variants, as useful environments for promoting social innovation and entrepreneurial learning. However, challenges posed regarding the different special target groups need to be addressed.

\section{Makerspaces and Maker Education}

For about fifteen years the number of makerspaces has been growing steadily. The core drivers have been more easily available digital design and fabrication tools (e.g. 3D printing), mostly based on open-source software and hardware, and the "maker movement" which promotes (digital) Do-It-Yourself (DIY) making and sharing of tools and knowledge. Maker media, online sharing platforms and a wave of large maker fairs and weeks (e.g. European Maker Week) and local maker days have spread the spirit and practice of "making" worldwide.

Makerspaces can take different forms in terms of organization, where they are established, available tools, and what is being produced (Schön, Ebner, \& Kumar, 2014). However, according to the literature they share some aspects, which include that a makerspace typically is:

- run by or on behalf of a local community or public institution,

- publicly-accessible, freely or based on a moderate membership fee,

- equipped with a variety of tools for creative work by like-minded people, 
- promotes collaboration on projects and knowledge sharing, and

- includes educational activities with a focus on hands-on "learning by doing".

"Makerspaces" is the general term for all creative environments that are based on maker principles. These include Fab Labs, Hackerspaces and various other makerspaces. Their focus and geographical diffusion is summarized below ${ }^{1}$.

Fab Labs: are laboratories with a focus on digital design and fabrication using computer-controlled 3D printing, laser cutting and other tools. Such labs are often established by or are closely related to universities as spaces for education, research and innovation. Most Fab Labs are members of a network coordinated by the Fab Foundation. These agree to provide a minimum core set of tools, be accessible and share knowledge. Looking into the member registry we found over $1300 \mathrm{Fab}$ Labs existing worldwide, up from 128 established and 28 planned labs on the first online list of the MIT Center for Bits and Atoms in 2012. In the European Union member states (EU28), and including Serbia as a partner country in DOIT, we identified 690.

Table 1

\begin{tabular}{|c|c|c|c|c|}
\hline $\begin{array}{l}\text { Makerspace } \\
\text { types }\end{array}$ & Focus & Main settings & $\begin{array}{l}\text { World } \\
\text { wide }\end{array}$ & $\begin{array}{l}\text { EU28+ } \\
\text { Serbia }\end{array}$ \\
\hline Fab Labs & $\begin{array}{l}\text { Digital fabrication, 3D design } \\
\& \text { printing, laser cutter and } \\
\text { other tools }\end{array}$ & $\begin{array}{l}\text { Members of the Fab } \\
\text { Foundation network }\end{array}$ & 1321 & 690 \\
\hline Hackerspaces & $\begin{array}{l}\text { Programming, open hardware / } \\
\text { software, electronics, sensors, } \\
\text { robotics }\end{array}$ & $\begin{array}{l}\text { Computer and } \\
\text { programming centres, } \\
\text { clubs }\end{array}$ & 1412 & 533 \\
\hline $\begin{array}{l}\text { Other } \\
\text { Makerspaces }\end{array}$ & $\begin{array}{l}\text { Creative cultural and social } \\
\text { engagement, using various } \\
\text { digital and other tools }\end{array}$ & $\begin{array}{l}\text { Community centres, } \\
\text { libraries, museums, } \\
\text { arts \& crafts groups }\end{array}$ & unknown & $\begin{array}{c}400 \\
\text { (estimate) }\end{array}$ \\
\hline
\end{tabular}

Hackerspaces: are mainly community-based and have a focus on programming and sharing of open-source software, but for some years have been expanding their activities to include open hardware, circuits, electronic components, and sensors. The hackerspaces wiki provides a community-maintained list of such spaces worldwide; on this list 1412 hackerspaces are marked as active and 357 as planned. In the EU28 and Serbia we identified 533 active ones.

Makerspaces: are various creative environments set up by local communities, schools or after-school clubs, libraries, museums and other public or civil society organizations. These provide mixed sets of tools (including some mentioned above), but all promote creative forms of cultural and social engagement. Their number worldwide is unknown, but based on different sources we estimate that in Europe there could be around 400 with a relative intensive use of digital tools.

\section{Emerging Makerspaces in Schools}

In schools around Europe the development of makerspaces is at an early stage. There are pioneering schools in some countries, especially in the Nordic countries, and first pilot projects funded by ministries, municipalities, foundations and others to explore and evaluate educational benefits. The European Schoolnet's Open Book of Educational 
Innovation (2017), a mapping of innovation initiatives in Europe, includes makerspaces under the category "Innovating pedagogical options and holistic changes". The authors see a "significant uptake" of the maker approach in schools and give as an example the large pilot Maker@Scuola (2014-2018) in Italy, which involved almost 100 nursery and primary schools. The pilot had a focus on using 3D design \& printing and other tools for creative projects (Guasti \& Rosa, 2017).

In Sweden the Makerskola pilot (2015-2018) explored how to turn traditional craft workshops into makerspaces. About 40 nursery, primary, secondary and special education schools have been involved (Eriksson et al., 2018; http://makerskola.se). In Denmark the FabLab@school.dk project (2014-2017), funded by the Danish Industry Foundation, introduced over 30 schools to digital design and fabrication for education (fab-learning) at the upper primary and lower secondary levels. Supported by their municipalities ten established a fab-learn laboratory. In the project also a Masters level course for teachers at Aarhus University with a focus on design processes and digital fabrication was developed (Bødker et al., 2017; Hjorth et al., 2016; Iversen, 2017).

\section{Maker Education}

"Maker Education" has a different meaning for different communities related to makerspaces. For FabLabs and Hackerspaces it means the learning that takes place when young people learn from experienced members as well as in joint projects with others. This aspect also informs learning opportunities these makerspaces offer as educational programs for children or groups of pupils from local schools.

For many teachers maker education means that activities with technical tools promote Science, Technology, Engineering and Mathematics (STEM) learning that is one of the priorities on the agenda of the educational systems worldwide. The same notion informs activities of other institutions with an educational component, for example, traditional museums of science, technology and industry, or the new variant of science centers that have included a makerspace in their educational programs.

Thus in these variants of "maker education" activities of "making", STEM learning and the potential for future technical invention are closely connected (Honey \& Kanter, 2013; Martinez \& Stager, 2013). Making this connection has been an effective way to promote makerspaces and maker tools, including the setting up of makerspaces with 3D printers, toolkits for children (e.g. Makey Makey or Calliope) and other digital and physical tools in schools as well as museums and public libraries.

Because of the narrow focus on STEM learning this large wave of "maker education" does not link up with entrepreneurship education and the theme of social innovation. DOIT suggests avoiding such a focus and instead engage young people through addressing social and environmental issues. When they work on such issues, STEM learning may follow, because young people, especially girls, will naturally take an interest in technologies relevant for their projects. For example, what do the social statistics say about the problem or how does an environmental sensor really work?

The DOIT learning program (see below) represents a different paradigm of maker education that focuses on practice-oriented social innovation and entrepreneurial learning of young people (aged 6-16 years) based on activities in makerspaces. This distinguishes the DOIT program from makerspace-based STEM learning, but also from typical Entrepreneurship Education. 


\section{Maker Education and Entrepreneurship Education: Different and Common Aspects}

Typical entrepreneurship education programs for children and young people mostly focus on learning about and for future entrepreneurship (e.g. what makes an entrepreneur, business idea creation, business plan writing), while some also include tentative entrepreneurial activity (e.g. the "mini-company" concept). These programs lack the engaging practical focus of developing a product or service that might help solving a social or environmental problem. Among the programs of the major international providers of entrepreneurship education for children and young people, Aflatoun, BizWorld.org and JA - Junior Achievement, only BizWorldPRO includes making products from simple craft materials. However, this is only one of the many items of the program, not a core activity.

The DOIT approach is practice-based ("making") from the onset and provides a learning journey from identifying a local issue to presenting a prototypic or minimal viable solution in public, to potential users and sponsors. Entrepreneurial questions such as who will adopt the solution (market) and resources required to provide it (costs, financial support) are infused during the making and learning process. This can serve as a pre-stage to learning more about business aspects of entrepreneurial activity.

Early entrepreneurship education and maker education (as promoted by DOIT) share a focus on such essential attitudes and competences such as self-confidence, creativity, teamwork, among others (see Figure 1). Where early entrepreneurial education is combined with maker activities this also allows fostering design and technical skills, including in the productive use of digital tools.

\section{Addressed competence development through early entrepreneurship education andlor maker education}

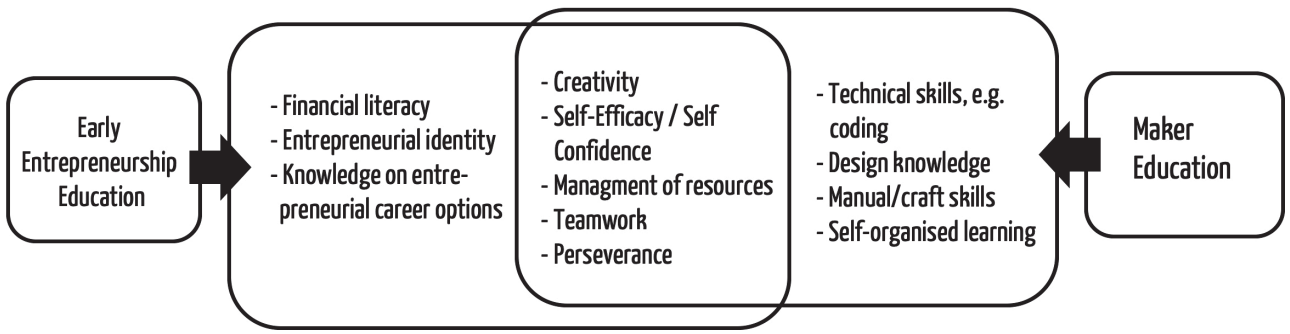

Figure 1. Competence development through early entrepreneurship education and/or maker education. The figure refers to competencies highlighted in European Commission et al. (2016) (Figure 3.7); Lindner (2018); Lackéus (2015); Schön \& Ebner (2017)

What must be considered is that for pupils in early entrepreneurship learning programs and/or maker education it will take many years until they enter professional life and may at some point consider starting a social enterprise or engaging with their skills in civil society initiatives for sustainable development (Ohlmeier, 2013). Therefore attempts to promote innovative and entrepreneurial activity must focus on essential competences, which pupils can carry forward into next stages of education, training and practical experiences.

Particularly important at an early stage is an encouraging approach that values the innovative ideas of pupils and students, and reduces fear of failure. With regard to valuing 
innovative ideas, results of the international Reflex and Hegesco surveys on graduates who work in different industries make clear that the perceived top 5 skills of innovative people are (in this order): come up with new ideas and solutions, willingness to question ideas, present ideas to an audience, alertness to opportunities, and analytical thinking (Avvisati et al., 2013). Concerning fear of failure and, hence, avoidance of risk-taking, The Missing Entrepreneurs report 2017 of the OECD and European Commission alerts us that in the period 2012-2016 on average nearly half (46\%) of surveyed young people (18-30 years) in the EU viewed fear of failure as a barrier to entrepreneurship (across all OECD countries slightly below $40 \%$ ). Therefore, it is important to encourage young people to actively explore their innovative ideas in creative environments, which allow them to "fail forward" by learning what might work better, and that such learning is very positive.

\section{The DOIT Learning Journey for Young Social Innovators and Entrepreneurs}

The DOIT project develops, trials and evaluates a new approach that allows children and young people (6-16 years) to acquire skills and an entrepreneurial mind-set for turning creative ideas into potential social innovations. Researchers, practitioners and policy makers have suggested various definitions of social innovation (see the overviews in Rüede \& Lurtz 2012; TEPSIE, 2012).

In wider use is the Definition in the Open Book of Social Innovation: "Our interest is in innovations that are social both in their ends and in their means. Specifically, we define social innovations as new ideas (products, services and models) that simultaneously meet social needs and create new social relationships or collaborations. In other words, they are innovations that are both good for society and enhance society's capacity to act" (Murray et al., 2010, p. 3). This definition is referenced for example by the European Commission in the Guide to Social Innovation (European Commission, 2013, p. 6), and the Bureau of European Policy Advisors in Empowering People-Driving Change. Social Innovation in the European Union (BEPA, 2010, p. 9). It is also the reference definition in the DOIT project.

The DOIT learning program focuses on developing (digital) making, social innovation and entrepreneurial competences and skills of children and young people. Particularly the program aims to allow them the experience of being social innovators. The core model of the learning program is summarized in Table 2, including examples of supporting DOIT materials available online.

The model is action-focused and in its practical application includes activities, materials and tools that support social innovation and entrepreneurial thinking and skills development, e.g. DOIT open educational toolboxes for makers, encounters with social entrepreneurs, giving feedback on innovative ideas, business modelling using the business canvas method, and others. Indeed, DOIT expects that projects in the action program, or at least some of teams of young people, create advanced prototypes of applicable and possibly marketable solutions.

The model is also aligned with the widely recognized innovation spiral model of The Open Book of Social Innovation (Murray et al., 2010), and the scheme of actionbased entrepreneurial education suggested by Lackéus $(2013,2015)$. The latter takes account of the increasing complexity of required entrepreneurial competence development, if projects are expected to proceed from artefacts considered valuable by stake- 
holders and intended users, towards an experimental venture or, even, a sustainable business venture (Hornung-Prähauser et al., 2018).

Table 2

Overview of the DOIT Learning Program (Hornung-Prähauser et al., 2018; www.doiteurope.net/toolbox)

\begin{tabular}{|c|c|c|}
\hline $\begin{array}{l}\text { DOIT learning } \\
\text { program }\end{array}$ & $\begin{array}{l}\text { Social innovation and } \\
\text { entrepreneurial aspects }\end{array}$ & $\begin{array}{l}\text { DOIT materials available online } \\
\text { (examples) }\end{array}$ \\
\hline $\begin{array}{l}\text { 1. Do it because } \\
\text { you can (sensitise) }\end{array}$ & $\begin{array}{l}\text { Awareness of a social problem - } \\
\text { Motivation to do something about } \\
\text { it - Feeling to be able to work on it }\end{array}$ & $\begin{array}{l}\text { Motivating material (e.g. Crazy } \\
\text { Wishes); inspiring success stories, } \\
\text { www.doit-europe.net/success-stories }\end{array}$ \\
\hline $\begin{array}{l}\text { lat } \\
\text { explore) }\end{array}$ & $\begin{array}{l}\text { What is the challenge? Where is } \\
\text { a need? What can I / we do to } \\
\text { make a change? - Collect ideas for } \\
\text { potential social innovations }\end{array}$ & $\begin{array}{l}\text { Materials on how to identify social } \\
\text { issues and needs (e.g. Social Investi- } \\
\text { gation Board) }\end{array}$ \\
\hline $\begin{array}{l}\text { 3. Do it to } \\
\text { (work toge }\end{array}$ & $\begin{array}{l}\text { Build a tear } \\
\text { ideas the te }\end{array}$ & $\begin{array}{l}\text { Materials on how to w } \\
\text { and co-create (e.g. Proj }\end{array}$ \\
\hline $\begin{array}{l}\text { 4. Do it now } \\
\text { (create) }\end{array}$ & $\begin{array}{l}\text { First prototyping of ideas - Present, } \\
\text { iterate and improve the innovative } \\
\text { prototype }\end{array}$ & $\begin{array}{l}\text { Materials on how to prototype (e.g. } \\
\text { Hidden Assumptions); present the } \\
\text { prototype online }\end{array}$ \\
\hline $\begin{array}{l}\text { 5. Do it better } \\
\text { (reflect) }\end{array}$ & $\begin{array}{l}\text { Fail forward - Get feed- } \\
\text { he product idea }\end{array}$ & $\begin{array}{l}\text { Materials on how to get valuable } \\
\text { feedback (e.g. Reflect on the Process) }\end{array}$ \\
\hline $\begin{array}{l}\text { 6. Do more of it } \\
\text { (scale up) }\end{array}$ & $\begin{array}{l}\text { Plan the realisation of the product } \\
\text { idea - Develop business plan and } \\
\text { marketing material - Find support }\end{array}$ & $\begin{array}{l}\text { Materials on how to develop a first } \\
\text { business plan and find support (e.g. } \\
\text { Marketing Poster) }\end{array}$ \\
\hline $\begin{array}{l}\text { 7. Do inspire } \\
\text { others (share) }\end{array}$ & $\begin{array}{l}\text { Public presentation - Share the } \\
\text { story and results of the social inno- } \\
\text { vation project }\end{array}$ & $\begin{array}{l}\text { Materials on how to share (e.g. } \\
\text { Project Presentation); present the } \\
\text { project story online }\end{array}$ \\
\hline
\end{tabular}

First Experiences from DOIT Pilots in Austria and the Netherlands

The DOIT project runs two waves of pilots in ten European countries trialing the learning program (Austria, Belgium, Germany, Denmark, Spain, Finland, Croatia, Netherlands, Slovenia and Serbia). The pilots are being organized by makerspaces of all three categories: FabLabs, hackerspaces and other makerspaces, in schools and public libraries. In addition, temporary makerspace environments are set up in primary and lower secondary schools that do not have one yet. The minimum joint maker activities of the children or young people are 15 hours (in practice often more) which in pilots already conducted took place within two and half days up to four months.

The pilots have different societal topics such as living together (e.g. social inclusion, intercultural living), participation and rights (e.g. political involvement, privacy), environment and nature (e.g. resource efficiency, up-cycling). An important part of the pilots is also to involve groups of participants such as children and young people in rural regions or with disabilities, specifically girls, as they are typically underrepresented in makerspaces. Some pilots use low-tech makerspaces with a focus on crafts while others are more high-tech, e.g. using sensor technology, combined with coding and electronics, to build advanced prototypes. 
The pilots are being systematically documented regarding plans and outcomes, and evaluated with several methods, including standardized pre- and post-tests regarding creativity as well self-efficacy of the children and young people, interviews with the facilitators, feedback from the participants. Conclusions and recommendations derived from the empirical results will be published after the completion of both waves of pilots. At this stage we present prototypes of solutions developed by children, and first experiences and lessons learned in pilots. As examples, here we present outcomes of children's making in two different pilot settings and focused on different topics.

The first pilot action took place in a makerspace in the Public Library of Amsterdam operated by DOIT project partner Waag Society. It was an afterschool activity for children from 8 to 11 years old with 13 participants. First children analysed the system of the production and use of a pair of jeans by mapping out the product chain. By mapping out the process with laser cut icons, they developed a holistic view of the system and identified intervention points. After detecting these intervention points, they framed identified issues such as waste in problem definitions to develop solutions. They were asked to come up with a waste robot that could help solve the problem. The children prototyped potential solutions in two phases: In the first phase they crafted a physical prototype of the waste robot by combining and manipulating recycled materials like cardboard and plastics. In the second phase they made a more advanced prototype by using digital fabrication and electronic components. They used a laser cutter, a 3D printer, batteries, motors, buttons, LED and wheels for the prototype.

\section{From Waste to Invention (Makerspace, Netherlands, 8-11 years)}

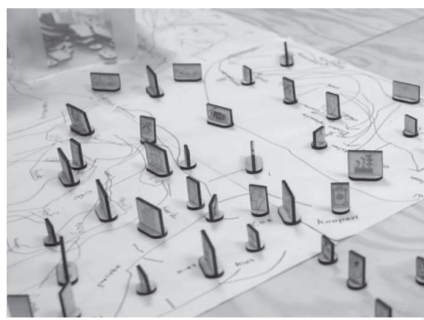

Mapping the product chain and lifecycle of a pair of jeans to explore waste and sustainability issues.

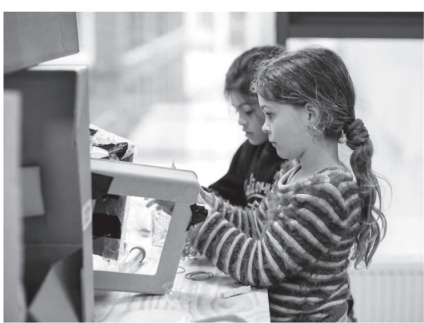

First prototyping with recycled materials: cardboard, cds, cups, lids, bags, etc.

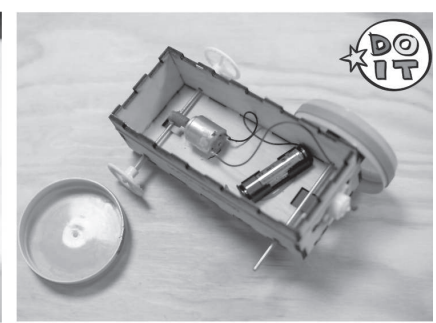

Second prototype for a car that runs on plants, with laser cut frame, DC-motor, battery, and wheels from recycled lids.

Figure 2. Photo impressions of the "From Waste to Invention" pilot process and results (Source: photographs and description by Waag, Amsterdam)

The second example comes from a pilot action with children from five to ten years in a temporary makerspace in an afternoon care setting of a primary school in Salzburg (use of three rooms in the school). The tools and materials for this "pop-up" makerspace were provided by Salzburg Research whose DOIT team managed the pilot. The pilot theme was "healthy food". In the pilot the children wanted to develop their own school's granola bar. As shown in Figure 3, it included all steps of product development from idea generation of children-friendly ingredients to prototyping and marketing.

The workshops for the healthy food pilot started with a presentation of a 3D printer, a technology, which the children had not seen before. The children asked how 
it works and what can be done with it. They were thrilled that a 3D printer can be used to make individual biscuit casters for the school's own granola bars. The children were split up into four groups, each working on suggestions for the ingredients, name and logo for the granola bars. After a brief presentation of the proposals to the plenary, the participants had to vote on their favorite recipe, name and logo. After the vote, all gathered again and discussed the results. Since the favorite name for the bar did not match its ingredients, there was an intense discussion, including the fairness of this vote. During the group discussion it was finally decided to use the name that also reflects the recipe, the name "chocolate power" for a granola bar with some cacao.

\section{School's Own Granola Bar (Day Care, Austria, 5-10 years)}

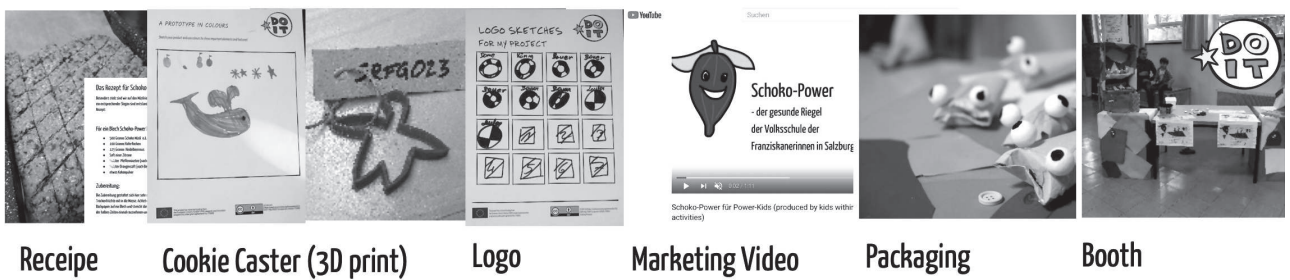

Figure 3. Photo impressions of the "Granola Bar" pilot process and results (Source: photographs and description by Salzburg Research, Salzburg)

In two afternoon sessions the children then developed a complete product concept, including marketing and sales. Each child could design its own form for the granola bar online with an easy-to-use 3D modeling tool for cookie casters (see cookiecaster.com). With limited access to computers and the Internet, only four children could work on their cookie caster models that were printed out later. Interestingly, this was not an issue at all, as many children did not want to "interrupt" their work in groups that worked on other parts of the product concept. These comprised a marketing video, an advertising poster, the product packaging and a sales booth that were designed and built. Regarding the packaging of the bars it was important for the children that it is sustainable, so they used cardboard and decorated it as "little monsters". The production of the marketing video involved the creation of figures, a stop motion animation and recorded sound. Time became a problem in this case, so that a facilitator had to take over the compilation of the video.

At the final presentation for the parents, the children presented very proudly the school's granola bar. The children were particularly motivated because they developed something for their school. Regarding the sale of the bars, they decided to offer them for a voluntary donation and to use the collected money for new maker equipment. Production for further school events is planned and the recipe has been published under an open license to make it freely available and promote that it is also used by others. 


\section{Summary of Experiences and Lessons Learned}

The DOIT pilot teams experienced makerspaces, in their different variants, as useful environments for promoting social innovation and entrepreneurial learning. Advanced technologies are clearly not the core element for such learning, but children are able to adopt them if they support the realization of their aspirations and ideas. The core element is the learning process guided by a social innovation model that also leads to questions such as who will adopt the innovative solution (market) and resources required to provide it (costs, financial support).

Issues of sustainability are being addressed in DOIT pilots on themes such as Environment and Nature (e.g. sustainable use of resources, waste management), Living Together (e.g. environmental and social issues in local community), Wellbeing, Health and Sport (e.g. healthy food and activities). The DOIT pilots invite children and young people to use maker methods and tools to develop creative, awareness-raising, and potentially sustainable solutions.

Reflecting on what does or does not work we find that the use of makerspaces and tools can help drive the learning process. However, it also poses challenges regarding the different special target groups considered in the DOIT project which must be addressed with targeted measures. For example, in rural areas there is a lack of established makerspaces but "pop-up" makerspaces can be used. This limits the availability of some more advanced tools (e.g. 3D printers, laser cutters and others) and, more importantly, the makerspace is also not available as a permanent social space to get together and jointly work on projects.

Children with disabilities deserve particular attention as they have various special needs, which pose a challenge but also an opportunity for makerspaces regarding inclusiveness as well as to develop innovative solutions for special needs. The opportunity for the children to use makerspaces to develop such solutions themselves should be highlighted. In all maker activities where technologies are being used, girls are typically underrepresented. In order to reach a higher participation this must be addressed with targeted gender-sensitive measures in the communication, organization and conduct of maker education (Schön et al., 2018). Such measures for instance include placing social questions before technical ones, and support female maker role models.

\section{Acknowledgement}

The DOIT project has received funding from the European Union's Horizon 2020 research and innovation program under grant agreement No 770063. The content of this publication does not reflect the official opinion of the European Union. Responsibility for the information and views expressed in the publication lies entirely with the authors. URL: www.doit-europe.net

Note:

(1) Sources for the numbers of Fab Labs and Hackerspaces are based on https://www.fablabs.io/ labs and https://wiki.hackerspaces.org (those marked as active), own extraction and calculation, some double entries removed. Other Makerspaces: Estimate based on various sources; only makerspaces with relative intensive use of digital tools, not including traditional workshops (e.g. wood or metal working, repair workshops, etc.). 


\section{References}

Aflatoun (2019). Homepage. Retrieved from https://www.aflatoun.org

Avvisati, F., Jacotin, G., \& Vincent-Lancrin, S. (2013). Educating higher education students for innovative economies: What international data tell us. Tuning Journal for Higher Education, 1(1), 223-240. Retrieved from http:/www.tuningjournal.org/ public/site/01/11_Educating_Higher_Education_Students_for_Innovative_ Economies.pdf

BizWorld.org (2019). Homepage. Retrieved from https://bizworld.org

Bødker, S., Dindler, C., \& Iversen, O. S. (2017). Tying the knots: Participatory infrastructuring at work. Computer Supported Cooperative Work, 26(1-2), 245-273. Retrieved from https://www.researchgate.net/publication/313728502

Eriksson, E. et al. (2018). Makerspace in school - considerations from a large-scale national testbed. International Journal of Child-Computer Interaction, 16, 9-15.

European Commission. (2013). Guide to social innovation. DG Regional and Urban Policy, Brussels. Retrieved from http://ec.europa.eu/regional_policy/sources/docgener/ presenta/social_innovation/social_innovation_2013.pdf

European Commission, EACEA, \& Eurydice. (2016). Entrepreneurship education at school in Europe. Luxembourg: Publications Office of the European Union. Retrieved from http://doi.org/10.2797/301610

European Schoolnet. (2017). Open book of educational innovation. Brussels. Retrieved from http://www.eun.org/documents/411753/817341/Open_book_of_Innovational_ Education.pdf

Guasti, L., \& Rosa, A. (2017). Maker@scuola-Stampanti 3D nella scuola dell'infanzia [Maker@scuola -3D printers in the nursery school]. Assopił Editore Firenze. Retrieved from http://www.indire.it/wp-content/uploads/2017/09/Libro-Maker-aScuola_2017.pdf

Hjorth, M. et al. (2016). Educating the reflective educator: Design processes and digital fabrication for the classroom. In Proceedings of FabLearn $2016-6^{\text {th }}$ Annual Conference on Creativity and Fabrication in Education, October 2016, Stanford, USA, 26-33. Retrieved from https://www.researchgate.net/publication/ 310506340

Honey, M., \& Kanter, D. E. (2013). Design, make, play: Growing the next generation of STEM innovators. New York: Routledge.

Hornung-Prähauser, V. et al. (2018). Social innovation training in makerspaces with the new DOIT approach. In Proceedings of the ISPIM conference 2018 in Stockholm. Manchester: The International Society for Professional Innovation Management (ISPIM), 1-15. Retrieved from https://www.salzburgresearch.at/publikation/socialinnovation-training-in-makerspaces-with-the-new-doit-approach/

Iversen, O. S. (2017).Fablab@school.dk: Building a FabLearn initiative on Participatory Design, May 2017. Retrieved from: http:/www.engagingexperience.dk/TLTL.pdf

JA - Junior Achievement. (2019). Homepage. Retrieved from https://www.jaeurope.org Lackéus, M. (2013). Developing entrepreneurial competencies - an action-based approach and classification in education. Chalmers University of Technology, Gothenburg, Sweden. Retrieved from http://vcplist.com/wp-content/uploads/2013/11/LackeusLicentiate-Thesis-2013-Developing-Entrepreneurial-Competencies.pdf 
Lackéus, M. (2015). Entrepreneurship in education. What, why, when, how. Entrepreneurship 360 - Background Paper. OECD LEED Division. Retrieved from https://www.oecd.org/cfe/leed/BGP_Entrepreneurship-in-Education.pdf

Lindner, J. (2018). Entrepreneurship education for a sustainable future. Discourse and Communication for Sustainable Education, 9(1), 115-127. Retrieved from doi.org/ 10.2478/dcse-2018-0009

Martinez, S. L., \& Stager, G. S. (2013). Invent to learn: Making, tinkering, and engineering the classroom. Torrance: Constructing Modern Knowledge Press.

Murray, R., Caulier-Grice, J., \& Mulgan, G. (2010). The open book of social Innovation. London: The Young Foundation \& NESTA. Retrieved from https://youngfoundation. org/publications/the-open-book-of-social-innovation

OECD \& European Commission. (2017). The missing entrepreneurs 2017. Policies for Inclusive Entrepreneurship. Paris: OECD Publishing. Retrieved from https://doi.org/ 10.1787/9789264283602-en

Ohlmeier, B. (2013). Civic education for sustainable development. Discourse and Communication for Sustainable Education, 4(1), 5-22. Retrieved from https://doi.org/ 10.2478/dcse-2013-0001

Rüede, D., \& Lurtz K. (2012). Mapping the various meanings of social innovation: Towards a differentiated understanding of an emerging concept. EBS Business School, Research Paper Nr. 12. Retrieved from http://dx.doi.org/10.2139/ssrn.2091039

Schön, S., Ebner, M., \& Kumar, S. (2014). The maker movement. Implications of new digital gadgets, fabrication tools and spaces for creative learning and teaching. In eLearning Papers, Special Edition 2014, 86-100. Retrieved from http://openlib. tugraz.at/56a88d76659bc

Schön, S., \& Ebner, M. (2017). Maker-Bewegung macht Schule: Hintergründe, Beispiele sowie erste Erfahrungen [Maker movement makes school: Background, examples and first experiences]. In Erpenbeck J., \& Sauter, W. (Eds.). Handbuch Kompetenzentwicklung im Netz [Handbook competence development in the Internet] (pp. 257-270). Stuttgart: Schäffer-Poeschel Verlag.

Schön, S. et al. (2018). How to support girls' participation at projects in makerspace settings. Overview on current recommendations. Poster presented at the EduRobotics Conference in Rome, 12 October 2018. Retrieved from https://www.researchgate. net/publication/328175572

TEPSIE - Theoretical, Empirical and Policy Foundations for Social Innovation in Europe. (2012). Defining social innovation. Caulier-Grice, J., Davies, A., Patrick, R., \& Norman, W. Project deliverable 1.1, 31 May 2012. Retrieved from https://young foundation.org/wp-content/uploads/2012/12/TEPSIE.D1.1.Report.Defining SocialInnovation.Part-1-defining-social-innovation.pdf

Correspondence relating this paper should be addressed to Sandra Schön, Salzburg Research Forschungsgesellschaft, coordinator of Coordinator of "DOIT - Entrepreneurial skills for young social innovators in an open digital world" (H2020-770063, 10/2017-09/2020, http://doit-europe.net).Email: sandra.schoen@salzburgresearch.at 